\title{
Determinants of Women's Choice of a Long-Acting Reversible Contraceptive in Boyolali, Central Java
}

\author{
Desy Eka Ilmiyah'), Uki Retno Budihastuti²), \\ Ismi Dwi Astuti Nurhaeni3), Ambar Mudigdo4) \\ ${ }^{1)}$ Masters Program in Public Health, Universitas Sebelas Maret \\ 2)Department of Obstetrics and Gynecology, Dr. Moewardi Hospital, Surakarta \\ 3)Faculty of Social and Political Sciences, Universitas Sebelas Maret \\ 4)Faculty of Medicine, Universitas Sebelas Maret
}

\begin{abstract}
Background: Long-acting reversible contraceptives (LARCs) are the most effective methods of birth control. LARCs include the copper IUD, the hormonal (progesterone) IUD, and the hormonal contraceptive implant (effective for 10, 5 and 3 years, respectively). These methods of birth control can prevent unwanted pregnancy up to 20 times better than birth control pills, patches, and vaginal rings. However, the use of LARCs remains low in Boyolali, Central Java, Indonesia. This study aimed to analyze the determinants of women's choice of a LARC in Boyolali, Central Java.

Subjects and Method: This was a case control study conducted in 25 community health centers, Boyolali District, Central Java, from April 24 to May 20, 2018. A sample of 200 women in reproductive age was selected by fixed disease sampling. The dependent variable was choice of a LARC. The independent variables were age, education, parity, knowledge, husband support, and counseling by health worker. The data were collected by questionnaire and analyzed by a logistic regression multilevel using Stata 13 program.

Results:Women's choice of the LARC increased with age $\geq 35$ years $(b=4.54 ; 95 \% \mathrm{CI}=1.69$ to $12.15 ; \mathrm{p}=0.003)$, education $\geq$ senior high school $(\mathrm{b}=4.59 ; 95 \% \mathrm{CI}=1.80$ to $11.70 ; \mathrm{p}=0.001)$, parity $\geq 3(\mathrm{~b}=7.15 ; 95 \% \mathrm{CI}=2.63$ to $19.44 ; \mathrm{p}<0.001)$, better knowledge $(\mathrm{b}=2.20 ; 95 \% \mathrm{CI}=0.88$ to 5.50 ; $\mathrm{p}=0.089)$, counseling by health worker $(\mathrm{b}=2.82 ; 95 \% \mathrm{CI}=1.11$ to $7.11 ; \mathrm{p}=0.028)$, and husband support ( $b=5.54 ; 95 \% \mathrm{CI}=2.15$ to $14.28 ; \mathrm{p}<0.001)$.

Conclusion: Women's choice of LARC increases with age $\geq 35$ years, education $\geq$ senior high school, parity $\geq 3$, better knowledge, counseling by health worker, and husband support.
\end{abstract}

Keywords: long-acting reversible contraceptive, women's choice, determinants

\section{Correspondence:}

Desy Eka Ilmiyah. Masters Program in Public Health, Universitas Sebelas Maret, Jl. Ir. Sutami 36 A, Surakarta 57126, Central Java. Email: desyekailmiyah@gmail.com

\begin{tabular}{l}
\hline BACKGROUND \\
\hline Long-acting reversible contraceptive \\
(LARC) in Indonesia has a low achievement \\
of acceptors of only $18.3 \%$ in 2014 and is \\
targeted to reach $23.5 \%$ by 2019 (BKKBN, \\
2015). The use of LARC has many \\
advantages both in terms of program and \\
user. The advantage of the program is to \\
reduce the Total Fertility Rate (TFR) to \\
reduce the rate of population growth in \\
Indonesia as the Millennium Development
\end{tabular}

Goals (MDGs). While the advantage in terms of users is that it is more efficient because it can be used in a long time, more secure and effective (Kurniawan et al., 2017). However, the number of LARC acceptors has decreased every year. The Indonesian population, especially the new contraceptive method participant, is more likely to use non-LARC contraceptive methods than MKJP (BKKBN, 2014). 
Modern contraceptive acceptors such as LARC have increased in all over the world from $54 \%$ in 1990 to $57.4 \%$ by 2014 (WHO, 2014). Indonesia has achieved $75 \%$ FP prevalence consisting of IUD (11.07\%) family planning acceptors, implants (10.46\%), vasectomy (o.69\%), tubectomy (3.52\%), condom $(3,15 \%)$, pills $(23.58 \%)$ and injection (47.54\%) (Benjamins, 2018).

Active contraceptive method participant in Central Java accounted for $79 \%$ of IUD (8.74\%), implants (11.48\%), vasectomy (0.99\%), tubectomy (5.32\%), condom (2, $32 \%)$, pill (14.47\%) and injection (56.67\%) (Ministry of Health, 2014). Data from Boyolali District Health Office shows the number of acceptors of LARC which is lower compared to Non LARC users with prevalence of LARC acceptors for about $37.8 \%$ and non LARC for about $62.2 \%$.

Many factors can influence a person in choosing a type of long-term contraceptive method. They are age, child sex, family and number of children (Hiremath et al., 2018). Husband's support also affects the contraceptive selection LARC because many women consider that decision makers in the family are husbands included in the health care (Durowade et al., 2017). In addition, couples need to conduct counseling on health personnel in determining the method of contraception that will be used. Counseling by health personnel is needed to eliminate misinformation and increase knowledge about the contraception (Benjamins, 2018). A good level of knowledge will influence the selection of LARC contraceptives (Ajong et al., 2016). A woman's education is also one of the factors that can influence the choice of contraceptive LARC (Yamamoto and Matsumoto, 2017). This is because a person with a high level of education will more easily accept a new idea so that it will be able to find the causes and solutions to determine which contraception will be used (Dewi and Notobroto, 2014).

Policy direction and strategies for using LARC in family planning services should be encouraged. The use of LARC is expected to reduce the drop-out rate by providing continuous information and family planning services (BKKBN, 2015). Low LARC acceptors can have an impact on population growth and fertility that will drive the number of deliveries. The high number of deliveries indirectly can increase maternal mortality (Ministry of Health, 2015).

Several studies have been conducted to determine the determinants of the choice of types of long-term contraceptive methods. The novelty in this study is to analyze age, education, parity, knowledge, counseling by health workers, and support of husbands with the selection of types of long-term contraceptive methods simultaneously. And other novelty is that the research was done at different places and times. Based on the above description, the researcher is interested in conducting a study about the determinant of choosing the type of long-term contraception method in Boyolali District.

\section{SUBJECTS AND METHOD \\ 1. Study Design \\ This was an analytic observasional study with a case control design. The study was conducted in Boyolali District, from 24 April to 20 May 2018.}

\section{Population and Sample}

The population of this study was all female contraceptive acceptors in Boyolali District. The case population was respondents using long-term contraceptive method. Meanwhile, the control population was the respondents who use non LARC. A sample of 200 women was selected by fixed disease sampling. 


\section{Study Variables}

The dependent variable was women choice on LARCs. The independent variables were age, education, parity, knowledge, health personnel counseling, and husband support.

\section{Operational Definition of Variables}

Women's choice of a long-acting reversible contraceptive was defined as the selection of contraceptive method such as implant, IUD, and tubectomy, in addition to such types of contraceptives such as pills and syringes are a type of non- LARCs.

Maternal age was defined as the age of the mother from birth until the time the data were taken. The data were collected by questionnaire. The measurement scale was continuous.

Education was defined as the highest educational level achieved by a person starting from elementary, junior high, high school, and college level. The data were collected by questionnaire. The measurement scale was categorical.

Parity was defined as the number of children born and still alive today. The data were collected by questionnaire. The measurement scale was continuous.

Knowledge was defined as maternal knowledge about long-term method of contraception. The data were collected by questionnaire. The measurement scale was continuous.

Counseling by health personnel was defined as a counseling that has been received by the respondents in the form of an explanation of the various - methods of LARCs by health personnel to assist women in decision making election of contraceptive method. The data were collected by questionnaire. The measurement scale was continuous.

Husband support was defined as husband's support for wife related to the contraception use. Type of support was in the form of informational, moral, and financial support. The data were collected by questionnaire. The measurement scale was continuous.

\section{Data Analysis}

The data were analyzed by univariate, bivariate, and multivariate analysis. Univariate analysis aims to explain each characteristic data. Bivariate analysis aims to analyze the relationship of two variables using SPSS with chi square test. Multivariate analysis uses a multiple logistic regression run on Stata 13.

\section{Research Ethics}

This study has obtained ethical clearance from health research ethics commission Dr.Moewardi hospital, Surakarta with letter number: 376 / III / HREC / 2018.

\section{RESULTS}

\section{Univariate Analysis}

Table 1 shows that subjects aged $\leq 35$ years were 98 mothers (49\%), and those aged> 35 years were 102 mothers (51\%). Mothers who have education <senior high school consisted of 94 mothers (47\%) and mothers who have education $\geq$ senior high school consisted of 106 mothers (53\%). Mothers with children $<3$ children consisted of 109 mothers ( $54.5 \%$ ), and who have children $\geq 3$ children were 91 mothers (45.5\%).

The proportion of mothers who have less knowledge was87 mothers (43.5\%) and mothers who have good knowledge were 113 (56.5\%). Mothers who received counseling were 93 mothers (46.5\%) and mothers who had received counseling were 107 mothers (53.5\%). Mothers with weak husband support were 98 mothers (49\%) and mothers with strong husband support were 102 mothers (51\%). 
Journal of Maternal and Child Health (2018), 3(3): 225-232

https://doi.org/10.26911/thejmch.2018.03.03.07

Table 1. The results of univariate analysis

\begin{tabular}{lcc}
\hline \multicolumn{1}{c}{ Variable } & Frequency & (\%) \\
\hline Age & & \\
$\leq 35$ years old & 98 & 49 \\
$>35$ years old & 102 & 51 \\
Education & & \\
<senior high school & 94 & 47 \\
$\geq$ senior high school & 106 & 53 \\
Parity & & \\
$<3$ children & 109 & 54,5 \\
$\geq 3$ children & 91 & 45,5 \\
Education & & \\
Less & 87 & 43,5 \\
Good & 113 & 56,5 \\
Counseling by & & \\
health personnel & & \\
Less & 93 & 46.5 \\
Good & 107 & 53.5 \\
Husband support & & \\
Weak & 98 & 49 \\
Strong & 102 & 51 \\
\hline
\end{tabular}

\section{Bivariat analysis}

Bivariate analysis looked at the relationship of independent variables of age, education, parity, knowledge, counseling by health personnel, and support of husbands with the dependent variable which is the choice of long-term contraceptive method.

Based on Table 2, the results of bivariate analysis using chi square showed the effect between age, education, parity, knowledge, counseling by health worker, and husband support for the selection of long-term contraceptive method. Women age $>35$ years were 9.01 times more likely to choose the LARCs, and it was statistically significant $(\mathrm{OR}=9.01 ; 95 \% \mathrm{CI}=4.75$ to 17.01; $\mathrm{p}<0.001)$.

Education variable showed that women with a level of education of $\geq$ senior high school were 7.83 times more likely to choose long-term contraception method than women who were $<$ senior high school. The result of analysis showed that there was a relationship between education and the choice of long-term contraception method which was statistically significant $(\mathrm{OR}=7.38 ; 95 \% \quad \mathrm{CI}=3.94$ to 13.83 ; $\mathrm{p}<0.001)$.

Table 2. Chi-Square analysis on the Determinants of Women's Choice of a LARCs

\begin{tabular}{|c|c|c|c|c|c|c|c|}
\hline \multirow{2}{*}{ Variable } & \multicolumn{2}{|c|}{ Non-MKJP } & \multicolumn{2}{|c|}{ MKJP } & \multirow{2}{*}{ OR } & \multirow{2}{*}{ 95\% CI } & \multirow[b]{2}{*}{$\mathbf{p}$} \\
\hline & $n=100$ & $\%$ & $\mathbf{n}=100$ & $\%$ & & & \\
\hline \multicolumn{8}{|l|}{ Age } \\
\hline$<35$ years old & 74 & $74 \%$ & 24 & $24 \%$ & \multirow[t]{2}{*}{9.01} & 4.75 to & \multirow[t]{2}{*}{$<0.001$} \\
\hline$\geq 35$ years old & 26 & $26 \%$ & 76 & $76 \%$ & & 17.01 & \\
\hline \multicolumn{8}{|l|}{ Education } \\
\hline$<$ senior high school & 70 & $70 \%$ & 24 & $24 \%$ & \multirow[t]{3}{*}{$7 \cdot 38$} & 3.94 to & \multirow[t]{2}{*}{$<0.001$} \\
\hline \multirow{2}{*}{\multicolumn{7}{|c|}{ Parity }} & \\
\hline & & & & & & & \\
\hline$<3$ children & 84 & $84 \%$ & 25 & $25 \%$ & \multirow[t]{2}{*}{$15 \cdot 75$} & 7.81 to & \multirow[t]{2}{*}{$<0.001$} \\
\hline$\geq 3$ children & 16 & $16 \%$ & 75 & $75 \%$ & & 31.73 & \\
\hline \multicolumn{8}{|l|}{ Knowledge } \\
\hline Less & 67 & $67 \%$ & 20 & $20 \%$ & \multirow[t]{2}{*}{8.12} & 4.26 & \multirow[t]{2}{*}{$<0.001$} \\
\hline Good & 33 & $33 \%$ & 80 & $80 \%$ & & to 15.45 & \\
\hline \multicolumn{8}{|c|}{$\begin{array}{l}\text { Counseling by health } \\
\text { personnel }\end{array}$} \\
\hline Less & 71 & $71 \%$ & 22 & $22 \%$ & \multirow[t]{2}{*}{8.68} & 4.57 to & \multirow[t]{2}{*}{$<0.001$} \\
\hline Good & 29 & $29 \%$ & 78 & $78 \%$ & & 16.47 & \\
\hline \multicolumn{8}{|l|}{ Husband Support } \\
\hline Weak & 78 & $78 \%$ & 20 & $20 \%$ & \multirow[t]{2}{*}{14.18} & 7.17 to & \multirow[t]{2}{*}{$<0.001$} \\
\hline Strong & 22 & $22 \%$ & 80 & $80 \%$ & & 28.02 & \\
\hline
\end{tabular}


Parity variable showed that women who have $\geq 3$ children were 15.75 times more likely to choose long-term contraception method than women who have $<3$ children. The result of analysis showed that there was a relationship between parity and the choice of long-term contraception method which was statistically significant $(\mathrm{OR}=15.75 ; \quad 95 \% \quad \mathrm{CI}=7.81$ to 31.73 ; $\mathrm{p}<0.001)$.

The result of analysis showed that there was a relationship between knowledge and the choice of long-term contraception method $(\mathrm{OR}=8.12 ; 95 \% \mathrm{CI}=4.26$ to $15.45 ; \mathrm{p}<0.001$ ).

There was a relationship between counseling by health personnel and the choice of long-term contraception method
$(\mathrm{OR}=8.68 ; 95 \% \mathrm{CI}=4.57$ to $16.47 ; \mathrm{p}<$ 0.001).

There was a relationship between husband support and the choice of longterm contraception method which was statistically significant $(O R=14.18 ; 95 \%$ $\mathrm{CI}=7.17$ to $28.02 ; \mathrm{p}<0.001)$.

\section{Multivariate Analysis}

From table 3, it can be seen that the choice of long-term contraception method was influenced by age, education, parity, knowledge, counseling by health personnel, and husband support.

Women's choice was positively affected by age $>35$ years old $(b=4.54 ; 95 \% \mathrm{CI}=$ 1.69 to $12.15 ; \mathrm{p}=0.003$ ), education of $\geq$ high school $(b=4.59 ; 95 \% \mathrm{CI}=1.80$ to $11.70 ; \mathrm{p}=$ o.001), parity $\geq 3(\mathrm{~b}=7.15 ; 95 \% \mathrm{CI}=2.63$ to 19.44; $\mathrm{p}<0.001$ ).

Table 3. The result of multiple logistic regression analysis of age, education, parity, knowledge, counseling by health personnel, and husband support on women's choice of long-term contraceptive method

\begin{tabular}{|c|c|c|c|c|}
\hline \multirow{2}{*}{ Dependent Variable } & \multirow[b]{2}{*}{ b } & \multicolumn{2}{|c|}{ 95\% CI } & \multirow[b]{2}{*}{$\mathbf{p}$} \\
\hline & & Lower Limit & Upper Limit & \\
\hline Age & 4.54 & 1.69 & 12.15 & 0.003 \\
\hline Education & 4.59 & 1.80 & 11.70 & 0.001 \\
\hline Parity & 7.15 & 2.63 & 19.44 & 0.000 \\
\hline Knowledge & 2.20 & 0.88 & 5.50 & 0.089 \\
\hline Counseling & 2.82 & 1.11 & 7.11 & 0.028 \\
\hline Husband Support & 5.54 & 2.15 & 14.28 & $<0.001$ \\
\hline \multicolumn{5}{|l|}{$\mathrm{N}$ observation $=200$} \\
\hline \multicolumn{5}{|l|}{$\log$ likelihood $=-63.42$} \\
\hline \multicolumn{5}{|l|}{ Pseudo R2 = 0.54} \\
\hline Prob. chi $^{2}<0.001$ & & & & \\
\hline
\end{tabular}

There was a positive association between knowledge and women's choice to LARCs. Women with good knowledge were 2.20 times more likely to use LARCs than women who have lack of knowledge $(b=$ 2.20; CI $95 \%=0.88$ to $5.50 ; p=0.089$ ).

There was a positive association between counseling by health personnel and women's choice to LARCs. Women who got counseling from health personnel were
2.82 times more likely to use LARCs than women who did not get counseling from health personnel $(b=2.82 ; 95 \% \mathrm{CI}=1.11$ to 7.11; $\mathrm{p}=0.028$ ).

There was a positive association between husband support and women's choice to LARCs. Strong husband support increased the likelihood of women's choice of LARCs $(b=5.54 ; 95 \% \mathrm{CI}=2.15$ to 14.28 ; $\mathrm{p}<0.001)$. 
From the analysis, it was known that the $\log$ likelihood score was -63.42 which indicated that there was compatibility between the model and the empirical data collected. While the score of pseudo R2 indicated that there were $54 \%$ variations of the choice of long-term contraception method determined by the 6 variables. The score of $\mathrm{prob}>\mathrm{chi}^{2}$ was less than 0.001 which showed a significant.

\section{DISCUSSIONS}

\section{The effect of maternal age on the women's choice of long-term contraception method}

The result of analysis showed that there was an effect of maternal age on the choice of long-term contraception method and it was statistically significant. Women at the age of $>5$ years old were more likely to choose long-term contraception method than women who were $\leq 35$ years old.

The result of this study was in line with a study by Olaolorun and Hindin (2014) that the use of modern contraceptives such as long-term contraception method was higher among women aged 3549 years old. This was because older women would tend to use long-term contraception in order to stop the pregnancy compared to younger women (Dambo et al., 2017)

\section{The effect of education on the} women's choice of long-term contraception method

The result of analysis showed that there was an effect of education on the choice of long-term contraception method and it was statistically significant. Women with education $\geq$ high school were more likely to choose long-term contraception.

The result of this study was in line with a study by Jalang et al. (2017), which showed that women with higher education were more likely to use LARCs than those with low education. Other studies have also shown that the higher a woman education, it would increase the likelihood of choosing sterilization by 1.4 times compared to women who had no formal education (Yamamoto and Matsumoto, 2017).

\section{The effect of parity on the women's choice of long-term contraception method}

The result of analysis showed that there was an effect of parity on the choice of longterm contraception method and it was statistically significant. Women who have $\geq 3$ children were more likely to choose long-term contraception method than women who have $<3$ children.

The result of this study was in line with a study by Islam (2016), which stated that women who have more than 2 children and who did not want more children were more likely to use long-term contraception method. This was because women felt that the number of children was already enough as desired by the family, therefore, they prefer long-term contraception method in preventing the pregnancy (Shimeka, 2015).

4. The effect of knowledge on the women's choice of long-term contraception method

The result of analysis showed that there was an effect of knowledge on the choice of long-term contraception method and it was statistically significant. Women who have good knowledge were more likely to choose long-term contraception method than women who have lack of knowledge.

The result of this study was in accordance with a study by Ajong et al. (2016), which stated that women who have good knowledge of various contraceptives tend to choose modern long-term contraception. This was also in line with a study done by Kari et al. (2013), which stated that women who have knowledge about longterm contraception method would be more 
interested in using long-term contraception. The most common reasons were because it was easier, effective, and provided long-term protection.

\section{The effect of counseling by health personnel on the women's choice of long-term contraception method} The result of analysis showed that there was an effect of counseling by health personnel on the choice of long-term contraception method and it was statistically significant. Women who got good counseling were more likely to choose longterm contraception method than women who got lack of counseling from health personnel.

The result of this study was in accordance with a study by Odu (2013), which showed that women would be more likely to use long-term contraception method after visiting the nearest health facility to get a counseling about contraception. In addition, women who get counseling by health personnel were more likely to use LARCs because they knew the long-term benefits of the selected contraception (Prateek and Saurabh, 2012).

\section{The effect of husband support on the women's choice of long-term contraception method}

The result of analysis showed that there was an effect of husband support on the choice of long-term contraception method and it was statistically significant. Women with strong husband support were more likely to choose long-term contraception method than women with weak support from their husband.

The result of this study was in accordance with a study by Mohammed et al. (2014), which stated that women who got support and often communicate with their husband would tend to use modern contraceptives such as LARCs. This was because many women still rely on their husbands in taking important decisions including health care because they considered that the decision makers in the family were their husbands (Durowade et al., 2017).

This study concluded that there was a positive and statistically significant relationship between age, education, parity, knowledge, counseling by health personnel, and husband support on the choice of longterm contraception method.

\section{REFERENCES}

Ajong AB, Njotang PN, Kenfack B, Yakum MN, Mbu ER (2016). Knowledge of women in family planning and future desire to use contraception: a cross sectional survey in Urban Cameroon. BMC Research Notes, 1-6. https://doi.org/10.1186/s13104-016-2155-7.

Benjamins LJ (2018). A Contraception Quality Improvement Initiative With Detained Young Woman: Counseling, Initiation, and Utilization. Journal of Pediatric and Adolescent Gynecology. https://doi.org/10.1016/j.jpag.2018.0 1.002.

BKKBN (2014). Pelayanan Kontrasepsi. Jakarta: BKKBN.

BKKBN (2015). Rencana Strategi Badan Kependudukan dan Keluarga Berencana Nasional Tahun 2015 - 2019. Jakarta.

Dambo ND, Yeremia I, Wallywahmed A (2017). Determinants Of Contraceptive Use By Woman In The Central Senatorial Zone Of Bayelsa State, Nigeria: A cross-sectional Survey. Nigeria medical journal. https://doi.org/10.4103/0300-1652.218409.

Dewi PH, Notobroto HB (2014). Rendahnya Keikutsertaan Pengguna Metode Kontrasepsi Jangka Panjang Pada Pasangan Usia Subur. Jurnal Biometrika dan Kependudukan. 
Durowade KA, Omokanye LO, Elegbede $\mathrm{OE}$, Olomofe $\mathrm{CO}$, Ajiboye $\mathrm{AD}$, Makinde A, Sanni TA (2017). Barriers to Contraceptive Uptake among Women of Reproductive Age in a Semi-Urban Community of Ekiti State, Southwest Nigeria. Ethiop J Health Sci. https://doi.org/10.4314/ejhs.v27i2.4.

Hiremath RN, Yadav AK, Ghodke S, Yadav $J$ (2018). Contraceptive use and its determinants amongst armed forces personnel. Medical Journal Armed Forces India, 2-6. https://doi.org/10.1016/j.mjafi.2016.12.007.

Islam A (2016). Prevalence and Determinants of Contraceptive use among Employed and Unemployed Women in Bangladesh. International Journal of MCH and AIDS (IJMA), 5(2), 92102. https://doi.org/10.21106/ijma.83.

Jalang R, Thuita F, Barasa SO, Njoroge P (2017). Determinants of contraceptive use among postpartum women in a county hospital in rural KENYA, $1-8$. BMC Public Health. https://doi.org/10.1186/s12889-017-4510-6.

Kari W, Kristine H, Joseph EP, Daniel G. 2013. Knowledge And Attitudes About Long Active Reversible Contraception Among Latina Women Who Desire Sterilization. Women Health Issues. https://doi.org/10.1016/j.whi.2013.o 5.001.

Kemenkes RI (2014). Profil Kesehatan Indinesia Tahun 2013. Jakarta. (2015). Profil Kesehatan Indonesia Tahun 2014. Jakarta.

Kurniawan, Hermawan, Rasyika N, Rahmat H (2017). Perilaku Akseptor Dalam Memilih Metode Kontrasepsi Jangka Panjang (MKJP) Di Poskesdes Anuta Singgani Kecamatan Mantikulore Kota Palu. Jurnal Preventif, 8(1).
Mohammed A, Woldeyohannes D, Feleke A, Megabiaw B (2014). Determinants of modern contraceptive utilization among married women of reproductive age group in North Shoa Zone, Amhara Region , Ethiopia, 1-7. Reproductive Health Journal. https://doi.org/10.1186/1742-4755-11-13.

Odu OO (2013). Barriers to use of modern contraceptives among women in an inner city area of Osogbo metropolis , Osun State, Nigeria, 647-655. International Journal of Women's Health. https://doi.org/10.2147/ijwh.s47604.

Olaolorun FM, Hindin MJ (2014). Having a Say Matters: Influence of DecisionMaking Power on Contraceptive Use among Nigerian Women Ages 35 - 49 Years, 9(6). Plos One Journal. https://doi.org/10.1371/journal.pone.0098 702.

Prateek SS, Saurabh RS (2012). Contraceptive practices adopted by women attending an urban health, 12(4). African Health Science. https://doi.org/10.4313/ahs.v124.3.

Shimeka TA (2015). Determinants of Long Acting Contraceptive Use among Reproductive Age Women in Ethiopia: Evidence from EDHS 2011. Science Journal of Public Health, 3(1), 143. https://doi.org/10.11648/j.sjph.2015 0301.33 .

WHO (2014). Maternal Mortality. World Health Organization.

Yamamoto Y, Matsumoto K (2017). Choice of contraceptive methods by women's status: Evidence from large-scale microdata in Nepal. Sexual and Reproductive Healthcare, 14, 48-54. https://doi.org/10.1016/j.srhc.2017.0 9.005 . 